\title{
Performance Improvement of Broad Crested Weirs
}

\author{
Bahzad M.A. Noori, \\ Dept. of Water Resources, \\ College of Engineering, \\ University of Mousl. \\ University of Dohuk. \\ Inam A.K. Juma, \\ Dept. of, Civil Engineering, \\ College of Engineering,
}

\begin{abstract}
In order to improve the performance of broad crested weirs, forty weir models were manufactured and tested and two hundred thirty six experiments were conducted in a laboratory horizontal channel of $10 \mathrm{~m}$ length, $0.3 \mathrm{~m}$ width and $0.45 \mathrm{~m}$ depth for a wide range of discharges. The performance of broad crested weir was improved by introducing an upstream face slope, rounding upstream corner and capping the upstream corner with a semi-cylinder in order to reduce the effect of flow separation. Analysis of experimental results showed that introducing an upstream slope face to square edge broad crested weir improved the performance and gave higher values of discharge coefficient. Rounding upstream corner increased the values of discharge coefficient and improved the performance of the weir. Also, capping the upstream corner with semi-cylinder improved the performance of the weir and gave higher values of discharge coefficient. Two empirical equations were obtained to estimate the value of discharge coefficient in terms of effective head to crest height ratio, upstream corner radius to crest height ratio and radius of cap to crest height ratio with high correlation coefficients.
\end{abstract}

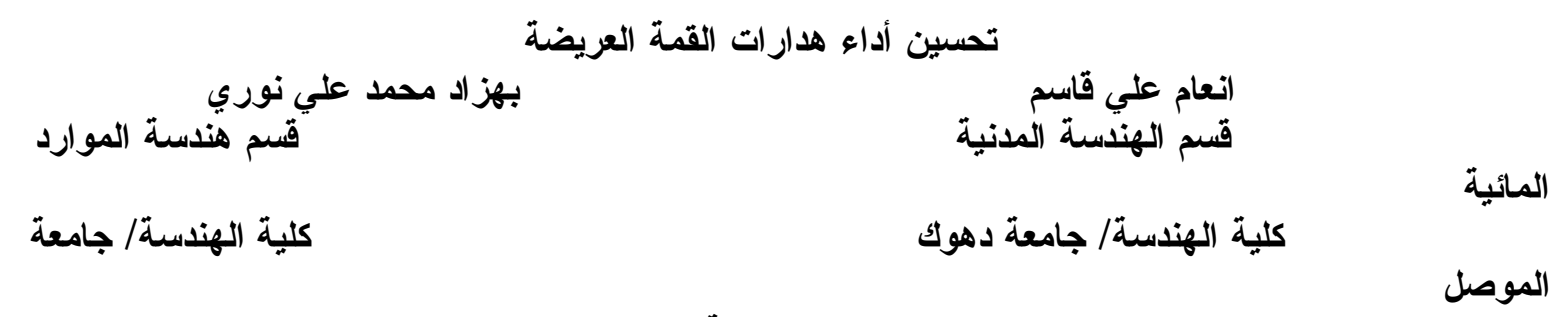

\section{الخلاصة}

لتحسين أداء الهدارات ذات القمة العريضة نم إنشاء واختبار أربعين نموذجا منها، و إجراء مائتان و ستة

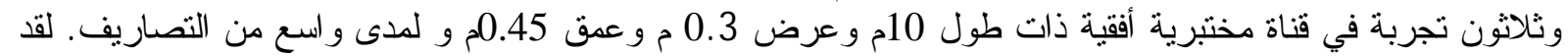

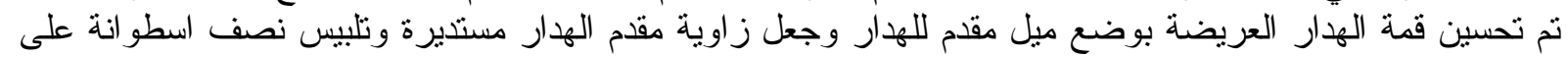

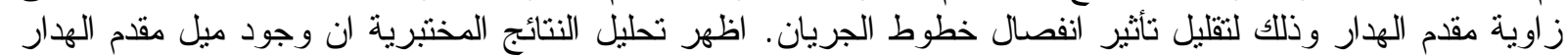

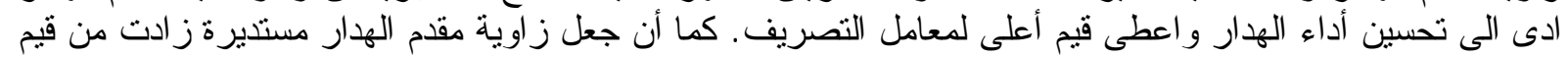

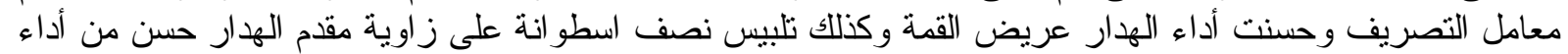

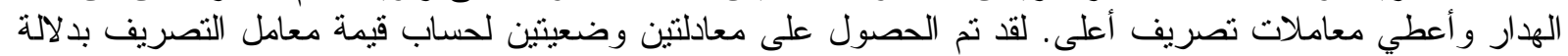

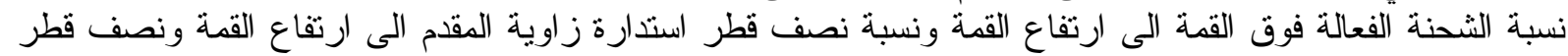
اسطو انة التلبيس الى ارتفاع القمة وبمعاملات ارتباط الفئ عالية. 


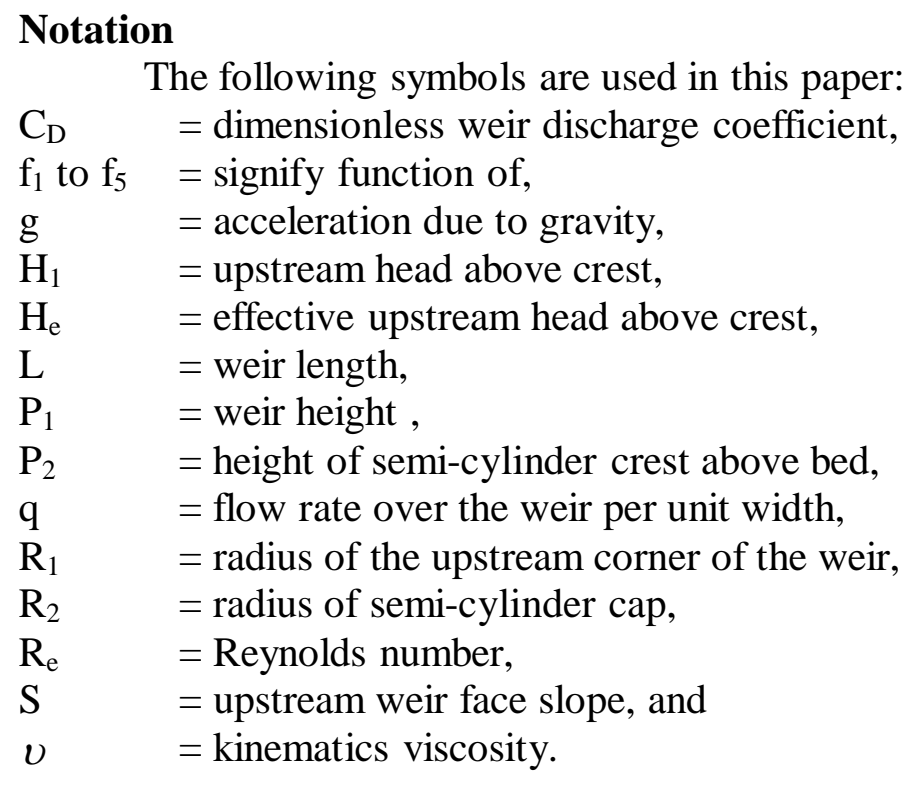

\section{Introduction}

Broad crested weirs are low cost and simple overflow structures widely used for flow measurements in field and laboratory channels. Moreover, broad crested weirs have an advantage of good range of flow rates and high modular limit. For square edge upstream corner, a separation zone appears as a dead water zone and consequently decreasing the effective head above the crest, rounding this zone, or rounding the upstream corner increases the discharge coefficient and decreases the silt deposition at upstream face especially for small weir heights ( Ramamurthy et al., 1988;Gogus et al., 2006).

The characteristics of flow over broad crested weirs have attracted the attention of many investigators to obtain empirical equations for the estimation of discharge coefficients (Tracy, 1957; Rao and Rao, 1973; Achers et al., 1978; Sarker and Rhodes, 2004; Gonzalez and Chanson,2007). Based on the boundary layer theory, Hall (1962) derived an expression for the free flow and submerged conditions of square edge broad crested weirs. The corner separation of square edge broad crested weir was analyzed by Moss (1972) concluding that the length of separation zone is $77 \%$ of head above crest and its height is $15 \%$ of head above crest. Hydraulic features of flow over square edge broad crested weirs with vertical upstream face were studied experimentally by Crabbe (1963) and Hager et. al. (1994).

Govinda Rao and Muralidhar (1963) classified weirs as broad crested weirs if the ratio of head above crest $\left(\mathrm{H}_{1}\right)$ to weir length $(\mathrm{L})$ is greater than 0.1 and less than 0.4 , while, Singer (1964) went to a limit as wide as $0.08<\mathrm{H}_{1} / \mathrm{L}<5$.6. Rao and Shukla (1971) studied experimentally the effect of finite crest length on discharge characteristics of broad crested weirs with square and elliptical upstream corners. Ramamurthy et al. (1988) gave a condition that the upstream corner of broad crested weir is considered sharp if the radius of curvature at this corner is less than $9.4 \%$ of weir height. Johnson (2000) conducted experiments on flattopped and sharp-crested weirs presenting his results in the formation of a single curve to estimate the discharge coefficient values. The effect of upstream face inclination on the characteristics of rectangular broad crested weirs was studied by Replogle (1978), Clemmens et al. (1984) and Bos et al. (1984) giving design tables for a wide range of variables.

In the present investigation, the main objective is to study the effects of upstream sloping face in order to reduce the dead water region in the upstream approach, rounding of the upstream top corner of the weir and capping the upstream separation zone with semicylinder on the characteristics of flow above broad crested weirs. 


\section{Theoretical Considerations}

The broad crested models are based on the following assumptions: flow upstream of weir is steady, sub-critical and two dimensional; the effects of flow surface tension and viscosity are eliminated. For rectangular broad crested weir assuming the critical flow on the weir crest, the equation for flow rate is written as (Boiten, 2002):

$$
q=C_{D} \times \frac{2}{3} \times H_{e} \sqrt{\frac{2}{3} g H_{e}}
$$

where,

$\mathrm{q}$ = flow rate over the weir per unit width,

$\mathrm{C}_{\mathrm{D}}=$ dimensionless weir discharge coefficient,

$\mathrm{H}_{\mathrm{e}}=$ effective upstream head above crest including approach velocity head

$$
=H_{1}+\frac{q^{2}}{2 g\left(P_{1}+H_{1}\right)^{2}},
$$

$\mathrm{H}_{1}=$ upstream head above crest,

$\mathrm{P}_{1}=$ weir height, and

$\mathrm{g}=$ acceleration due to gravity.

For a free flow over broad crested weir with square or rounded upstream corner, a functional relationship can be written as follows(see Figs(1a) to (1d)) :

$$
f_{1}\left(q, H_{e}, P_{1}, R_{1}, g, S, v\right)=0
$$

where,

$\mathrm{R}_{1}=$ radius of the upstream corner of the weir,

$\mathrm{S}=$ upstream weir face slope, and

$v=$ kinematic viscosity.

Using Buckingham Pi-theorem and after certain permissible manipulations, Eq.(2) becomes:

$$
\begin{aligned}
C_{D} & =\frac{q}{\frac{2}{3} H_{e}\left(\frac{2}{3} g H_{e}\right)^{\frac{1}{2}}}=f_{2}\left(\frac{H_{e}}{P_{1}}, \frac{R_{1}}{P_{1}}, S, R_{e}\right) \\
\mathrm{R}_{\mathrm{e}} & =\text { Reynolds number. }
\end{aligned}
$$

Reynolds number will have very large values and hence its effect on $C_{D}$ will be very little, therefore, $\mathrm{R}_{\mathrm{e}}$ can be dropped and Eq.(3) can be written as:

$$
C_{D}=f_{3}\left(\frac{H_{e}}{P_{1}}, \frac{R_{1}}{P_{1}}, S\right)
$$

For rectangular broad crest weirs with upstream sloping face, Eq.(4) can be expressed as:

$$
C_{D}=f_{4}\left(\frac{H_{e}}{P_{1}}, S\right)
$$

Another method of improving the efficiency of the crest is to introduce a semicylinder of radius $\mathrm{R}_{2}$ at the upstream separation zone (see Fig.1e), consequently, for this case, Eq.(5) can be written as:

$$
C_{D}=f_{5}\left(\frac{H_{e}}{P_{2}}, \frac{R_{2}}{P_{2}}, S\right)
$$

where,

$\mathrm{P}_{2}=$ height of cylinder crest above bed. 


\section{Experimental Setup And Procedure}

In order to check the validity of the proposed relationships, an intensive experimental program was carried out by testing different models of broad crested weirs of different cases. These models were tested in a horizontal glass walled tilting channel of $10 \mathrm{~m}$ length, $0.3 \mathrm{~m}$ width and $0.45 \mathrm{~m}$ depth. A moveable carriage with a point gauge was mounted on brass rails at the top of channel sides. Forty weir models were manufactured and tested each having a specific condition. The first model was rectangular with square edge upstream and downstream of $0.45 \mathrm{~m}$ length and $0.15 \mathrm{~m}$ height (Fig. (1a)). For the following four models, the upstream face was given slopes $(\mathrm{S})$ of $(0.5 \mathrm{H}: 1 \mathrm{~V}),(1 \mathrm{H}: 1 \mathrm{~V}),(2 \mathrm{H}: 1 \mathrm{~V})$, and $(3 \mathrm{H}: 1 \mathrm{~V})$, i.e., $\mathrm{S}=2,1,0.5$ and 0.33 respectively (Fig.(1b)). In the following five models the upstream corner was rounded to radii $\left(\mathrm{R}_{1}\right)=1.5 \mathrm{~cm}, 6 \mathrm{~cm}, 9 \mathrm{~cm}, 12 \mathrm{~cm}$ and $15 \mathrm{~cm}$ respectively (Fig. (1c)) and keeping the upstream face vertical. For models eleven to fifteen the upstream face slope was kept $(0.5 \mathrm{H}: 1 \mathrm{~V}, \mathrm{~S}=2)$ and the upstream corner radius $\left(\mathrm{R}_{1}\right)$ changed five times from $1.5 \mathrm{~cm}$ to $15 \mathrm{~cm}$ (Fig.(1d)). In the models sixteen to twenty, the upstream edge was capped with semicylinder of radius $\left(\mathrm{R}_{2}\right)=1 \mathrm{~cm}$ and the upstream slope $(\mathrm{S})$ was varied five times from $\quad(0 \mathrm{H}$ : $1 \mathrm{~V})$ to $(3 \mathrm{H}: 1 \mathrm{~V})$, see Fig. (1e). For the remaining models radius of semi-cylinder $\left(\mathrm{R}_{2}\right)$ was changed to $2 \mathrm{~cm}, 3 \mathrm{~cm}, 4 \mathrm{~cm}$ and $5 \mathrm{~cm}$ and for each radius the upstream face slope was varied five times from vertical $(0 \mathrm{H}: 1 \mathrm{~V})$ to $(3 \mathrm{H}: 1 \mathrm{~V})$ as shown in Fig.(1e). Details of the tested weir models and the experimental program are shown in Table (1).

\section{Analysis Of Results \\ Upstream Face Slope}

A way of improving the performance of broad crested weir is to introduce an upstream face slope to the upstream square edge. The effect of upstream face slope on the behavior of broad crested weirs was studied by testing five weir models of different cases, the first weir model was broad crested with vertical upstream face( square edge), i.e., with slope(0H:1V), while, the other four were of slopes $(0.5 \mathrm{H}: 1 \mathrm{~V}),(1 \mathrm{H}: 1 \mathrm{~V}),(2 \mathrm{H}: 1 \mathrm{~V})$ and $(3 \mathrm{H}: 1 \mathrm{~V})$. Fig. (2) shows the experimentally determined relationships between $\mathrm{C}_{\mathrm{D}}$ and $\mathrm{H}_{\mathrm{e}} / \mathrm{P}_{1}$ for the five cases studied showing that $\mathrm{C}_{\mathrm{D}}$ increases with the increase of $\mathrm{H}_{\mathrm{e}} / \mathrm{P}_{1}$ for all slopes and existence of upstream slope gives higher values of discharge coefficient $\left(\mathrm{C}_{\mathrm{D}}\right)$.

From Fig.(2) one may conclude that an upstream face slope of $(0.5 \mathrm{H}: 1 \mathrm{~V}$ or $\mathrm{S}=2)$ is quite enough to give high values of $C_{D}$ among other slopes. This means that upstream slope flatter than $(0.5 \mathrm{H}: 1 \mathrm{~V})$ will not give improvement to the value of discharge coefficient and will be more expensive in construction. 


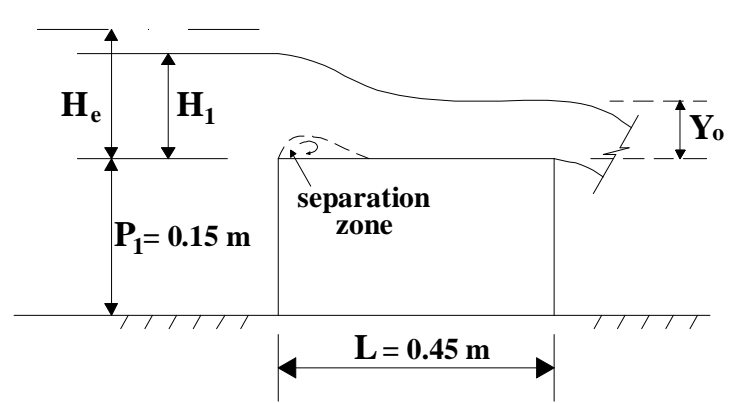

Fig. (1a) Flow over square edge weir with vertical upstream face (Model 1)

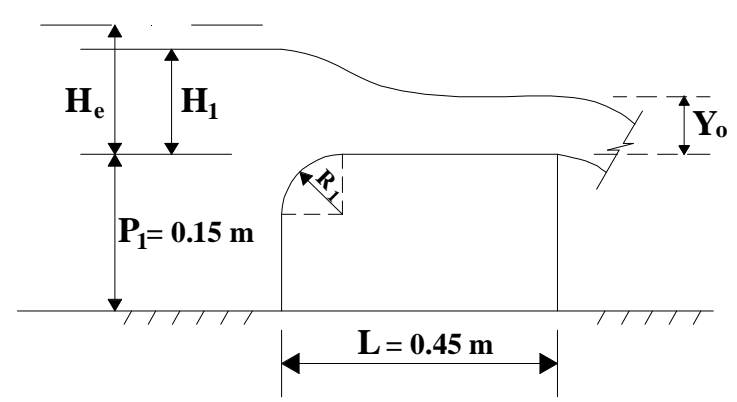

Fig. (1c) Flow over round edge weir with vertical upstream face (Models 6-10)

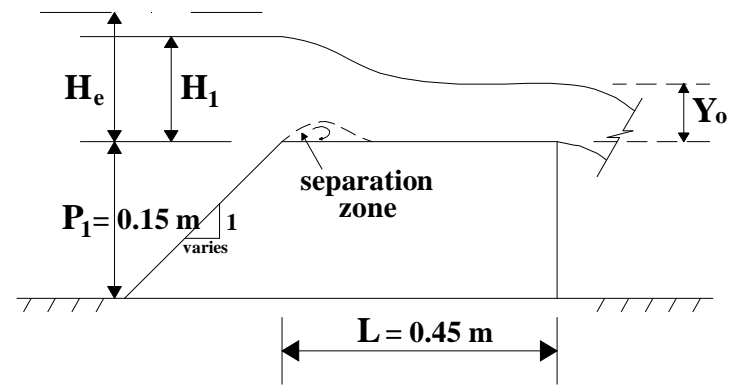

Fig. (1b) Flow overinclined upstream face weir (Models 2-5)

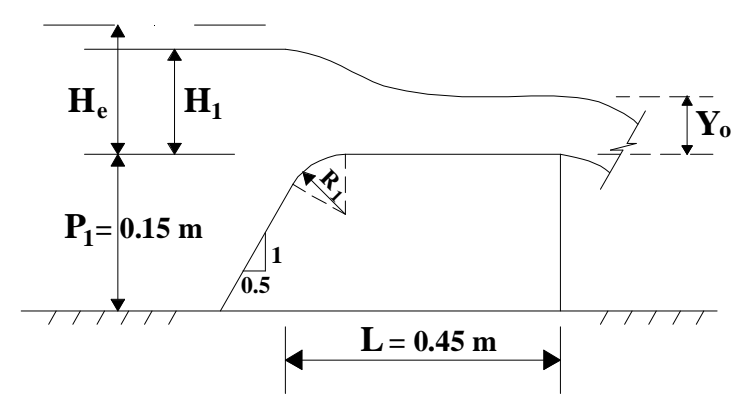

Fig. (1d) Flow over rounded edge and inclined upstream face weir (Models 11-15)

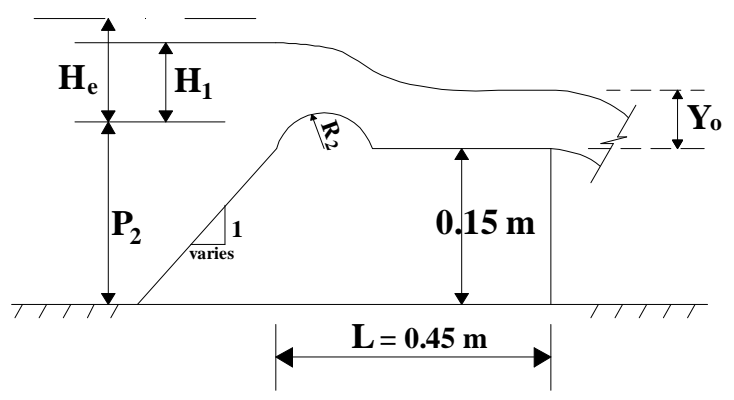

Fig. (1e) Flow over capped edge weir with inclined upstream face (Models 16 - 40)

Fig. (1) Definition sketches showing different cases tested 
Noori: Performance Improvement of Broad Crested Weirs

\begin{tabular}{|c|c|c|c|c|c|}
\hline $\begin{array}{c}\text { Mod } \\
\text { el } \\
\text { No. }\end{array}$ & $\begin{array}{l}\text { Run } \\
\text { No. }\end{array}$ & $\begin{array}{l}\text { Corner } \\
\text { Radius } \\
\mathbf{R}_{\mathbf{1}}(\mathbf{c m})\end{array}$ & $\begin{array}{c}\text { Range of } \\
\text { Effective Head } \\
H_{e}(\mathbf{c m})\end{array}$ & $\begin{array}{c}\text { Range of Flow } \\
\text { Rate } \\
\mathbf{q} \mathbf{m}^{3} /(\text { sec.m }) \\
* 10^{-3} \\
\end{array}$ & $\begin{array}{l}\text { U.S. Face } \\
\text { Slope } \\
\text { (S) }\end{array}$ \\
\hline $\begin{array}{l}1 \\
2 \\
3 \\
4 \\
5\end{array}$ & $\begin{array}{c}1-5 \\
6-11 \\
12-16 \\
17-21 \\
22-26\end{array}$ & $\begin{array}{l}0 \\
0 \\
0 \\
0 \\
0\end{array}$ & $\begin{array}{c}5.85-11.03 \\
3.36-9.26 \\
5.75-10.84 \\
5.76-10.94 \\
5.75-10.94\end{array}$ & $\begin{array}{r}19.81-55.15 \\
8.89-42.62 \\
19.81-55.15 \\
19.81-55.15 \\
19.81-55.15\end{array}$ & $\begin{array}{c}0 \mathrm{H}: 1 \mathrm{~V} \\
0.5 \mathrm{H}: 1 \mathrm{~V} \\
1 \mathrm{H}: 1 \mathrm{~V} \\
2 \mathrm{H}: 1 \mathrm{~V} \\
3 \mathrm{H}: 1 \mathrm{~V}\end{array}$ \\
\hline $\begin{array}{c}6 \\
7 \\
8 \\
9 \\
10\end{array}$ & $\begin{array}{l}27-32 \\
33-38 \\
39-44 \\
45-50 \\
51-56\end{array}$ & $\begin{array}{c}1.5 \\
6 \\
9 \\
12 \\
15\end{array}$ & $\begin{array}{l}3.36-9.21 \\
3.21-8.82 \\
3.19-8.67 \\
3.21-8.67 \\
3.19-8.65\end{array}$ & $\begin{array}{ll}8.89 & -42.62 \\
8.89 & -42.62 \\
8.89 & -42.62 \\
8.89 & -42.62 \\
8.89 & -42.62\end{array}$ & $\begin{array}{l}0 \mathrm{H}: 1 \mathrm{~V} \\
\mathrm{OH}: 1 \mathrm{~V} \\
0 \mathrm{H}: 1 \mathrm{~V} \\
\mathrm{OH}: 1 \mathrm{~V} \\
0 \mathrm{H}: 1 \mathrm{~V}\end{array}$ \\
\hline $\begin{array}{l}11 \\
12 \\
13 \\
14 \\
15\end{array}$ & $\begin{array}{l}57-62 \\
63-68 \\
69-74 \\
75-80 \\
81-86\end{array}$ & $\begin{array}{c}1.5 \\
6 \\
9 \\
12 \\
15\end{array}$ & $\begin{array}{l}3.35-9.16 \\
3.19-8.77 \\
3.16-8.64 \\
3.18-8.62 \\
3.19-8.62\end{array}$ & $\begin{array}{ll}8.89 & -42.62 \\
8.89 & -42.62 \\
8.89 & -42.62 \\
8.89 & -42.62 \\
8.89 & -42.62\end{array}$ & $\begin{array}{l}0.5 \mathrm{H}: 1 \mathrm{~V} \\
0.5 \mathrm{H}: 1 \mathrm{~V} \\
0.5 \mathrm{H}: 1 \mathrm{~V} \\
0.5 \mathrm{H}: 1 \mathrm{~V} \\
0.5 \mathrm{H}: 1 \mathrm{~V}\end{array}$ \\
\hline $\begin{array}{c}\text { Mod } \\
\text { el } \\
\text { No. }\end{array}$ & $\begin{array}{l}\text { Run } \\
\text { No. }\end{array}$ & $\begin{array}{c}\text { Cap } \\
\text { Radius } \\
\mathbf{R}_{2}(\mathbf{c m})\end{array}$ & $\begin{array}{c}\text { Range of } \\
\text { Effective Head } \\
\mathbf{H}_{\mathrm{e}}(\mathbf{c m})\end{array}$ & 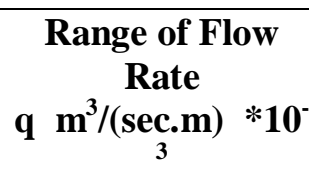 & $\begin{array}{l}\text { U.S. Face } \\
\text { Slope } \\
\text { (S) }\end{array}$ \\
\hline $\begin{array}{l}16 \\
17 \\
18 \\
19 \\
20\end{array}$ & $\begin{array}{c}87-92 \\
93-98 \\
99-104 \\
105-110 \\
111-116\end{array}$ & $\begin{array}{l}1 \\
1 \\
1 \\
1 \\
1\end{array}$ & $\begin{array}{l}3.31-8.85 \\
3.31-8.83 \\
3.26-8.80 \\
3.24-8.79 \\
3.29-8.81\end{array}$ & $\begin{array}{ll}8.89 & -42.62 \\
8.89 & -42.62 \\
8.89 & -42.62 \\
8.89 & -42.62 \\
8.89 & -42.62\end{array}$ & $\begin{array}{c}0 \mathrm{H}: 1 \mathrm{~V} \\
0.5 \mathrm{H}: 1 \mathrm{~V} \\
1 \mathrm{H}: 1 \mathrm{~V} \\
2 \mathrm{H}: 1 \mathrm{~V} \\
3 \mathrm{H}: 1 \mathrm{~V}\end{array}$ \\
\hline $\begin{array}{l}21 \\
22 \\
23 \\
24 \\
25\end{array}$ & $\begin{array}{l}117-122 \\
123-128 \\
129-134 \\
135-140 \\
141-146\end{array}$ & $\begin{array}{l}2 \\
2 \\
2 \\
2 \\
2\end{array}$ & $\begin{array}{l}3.25-8.79 \\
3.25-8.78 \\
3.24-8.77 \\
3.21-8.73 \\
3.21-8.74\end{array}$ & $\begin{array}{ll}8.89 & -42.62 \\
8.89 & -42.62 \\
8.89 & -42.62 \\
8.89 & -42.62 \\
8.89 & -42.62\end{array}$ & $\begin{array}{c}0 \mathrm{H}: 1 \mathrm{~V} \\
0.5 \mathrm{H}: 1 \mathrm{~V} \\
1 \mathrm{H}: 1 \mathrm{~V} \\
2 \mathrm{H}: 1 \mathrm{~V} \\
3 \mathrm{H}: 1 \mathrm{~V}\end{array}$ \\
\hline $\begin{array}{l}26 \\
27 \\
28 \\
29 \\
30\end{array}$ & $\begin{array}{l}147-152 \\
153-158 \\
159-164 \\
165-170 \\
171-176\end{array}$ & $\begin{array}{l}3 \\
3 \\
3 \\
3 \\
3\end{array}$ & $\begin{array}{c}3.21-8.6 \\
3.21-8.78 \\
3.23-8.60 \\
3.11-8.57 \\
3.16-8.58\end{array}$ & $\begin{array}{ll}8.89 & -42.62 \\
8.89 & -42.62 \\
8.89 & -42.62 \\
8.89 & -42.62 \\
8.89 & -42.62\end{array}$ & $\begin{array}{c}0 \mathrm{H}: 1 \mathrm{~V} \\
0.5 \mathrm{H}: 1 \mathrm{~V} \\
1 \mathrm{H}: 1 \mathrm{~V} \\
2 \mathrm{H}: 1 \mathrm{~V} \\
3 \mathrm{H}: 1 \mathrm{~V}\end{array}$ \\
\hline $\begin{array}{l}31 \\
32 \\
33 \\
34 \\
35\end{array}$ & $\begin{array}{l}177-182 \\
183-188 \\
189-194 \\
195-200 \\
201-206\end{array}$ & $\begin{array}{l}4 \\
4 \\
4 \\
4 \\
4\end{array}$ & $\begin{array}{l}3.21-8.72 \\
3.21-8.71 \\
3.20-8.70 \\
3.16-8.67 \\
3.21-8.66\end{array}$ & $\begin{array}{ll}8.89 & -42.62 \\
8.89 & -42.62 \\
8.89 & -42.62 \\
8.89 & -42.62 \\
8.89 & -42.62\end{array}$ & $\begin{array}{c}0 \mathrm{H}: 1 \mathrm{~V} \\
0.5 \mathrm{H}: 1 \mathrm{~V} \\
1 \mathrm{H}: 1 \mathrm{~V} \\
2 \mathrm{H}: 1 \mathrm{~V} \\
3 \mathrm{H}: 1 \mathrm{~V}\end{array}$ \\
\hline
\end{tabular}

Table(1): Details of the tested weir models 


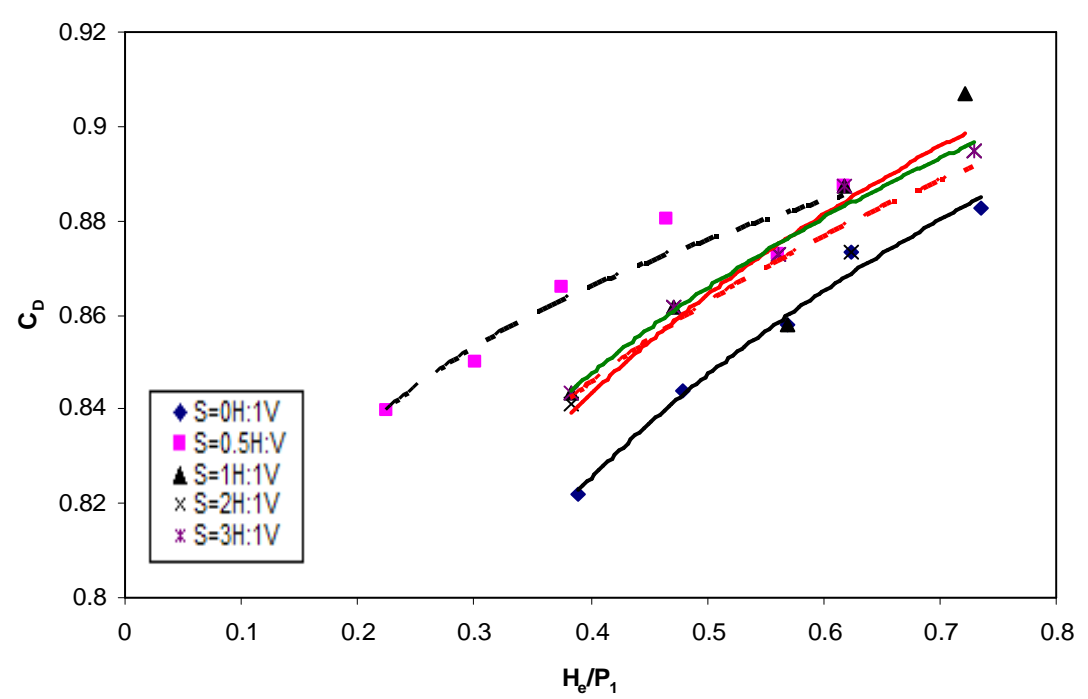

Fig.(2) Variation of $C_{D}$ with $H_{e} / P_{1}$ for different upstream weir face slopes

\section{Rounding Upstream Top Corner}

One of the main objectives of this study is to determine the effect of rounding upstream top corner on discharge coefficient. Eq.(4) indicates that one can find the effect of $\mathrm{H}_{\mathrm{e}} / \mathrm{P}_{1}$ and $\mathrm{R}_{1} / \mathrm{P}_{1}$ on $\mathrm{C}_{\mathrm{D}}$ by conducting tests on weir models for which the slope $(\mathrm{S})$ is held constant. The effect of rounding the upstream corner of the square edge broad crested weir is to increase the coefficient of discharge by reducing very much flow separation at the crest which is the primary source of energy loss. Fig.(3) shows the effects of $H_{e} / P_{1}$ and $R_{1}$ on $C_{D}$ by holding the upstream face vertical. From Fig.(3) one may observe that $C_{D}$ increases significantly with the increase of $\mathrm{H}_{\mathrm{e}} / \mathrm{P}_{1}$. Also, it can be observed that when $\mathrm{R}_{1}$ is greater than or equal to $9 \mathrm{~cm}$, the discharge coefficient reaches peak values which means that the flow separation is nearly vanished and further rounding beyond $R_{1}=9 \mathrm{~cm}$ does not alter the flow characteristics. The variation of average values of $C_{D}$ with $R_{1} / P_{1}$ is shown in Fig.(4) indicating that the average value of $C_{D}$ reaches the highest value when $R_{1} / P_{1}$ is equal to 0.6 and greater, this means that well rounding is reached. Fig.(5) shows the variation of $C_{D}$ with $\mathrm{H}_{\mathrm{e}} / \mathrm{P}_{1}$ for upstream face slope $(0.5 \mathrm{H}: 1 \mathrm{~V})$ and rounding the upstream top corner. In Fig.(5), it is shown that $\mathrm{C}_{\mathrm{D}}$ increases with the increase of $\mathrm{H}_{\mathrm{e}} / \mathrm{P}_{1}$ and well rounding of the top corner gives higher values of $C_{D}$. The variation of average values of $C_{D}$ with $R_{1} / P_{1}$ for round upstream top corner and upstream face slope $(0.5 \mathrm{H}: 1 \mathrm{~V})$ is shown in Fig.(6) showing slightly higher values of $C_{D}$ compared with those of weirs without slope and peak values of $C_{D}$ were obtained when $\mathrm{R}_{1} / \mathrm{P}_{1}$ reaches 0.6 and greater.

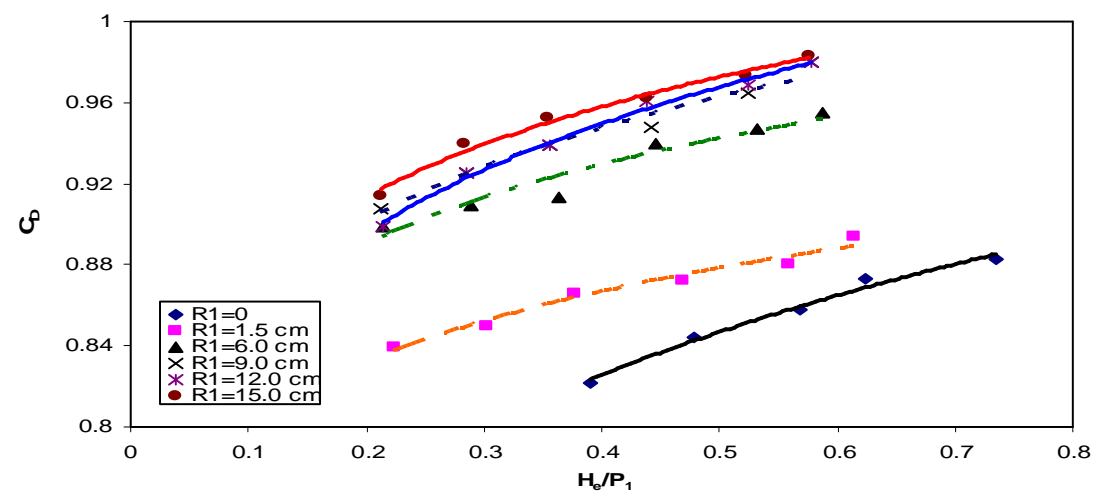

Fig.(3) Variation of $C_{D}$ with $H_{e} / P_{1}$ for different values of $R_{1}$ and vertical upstream weir face 


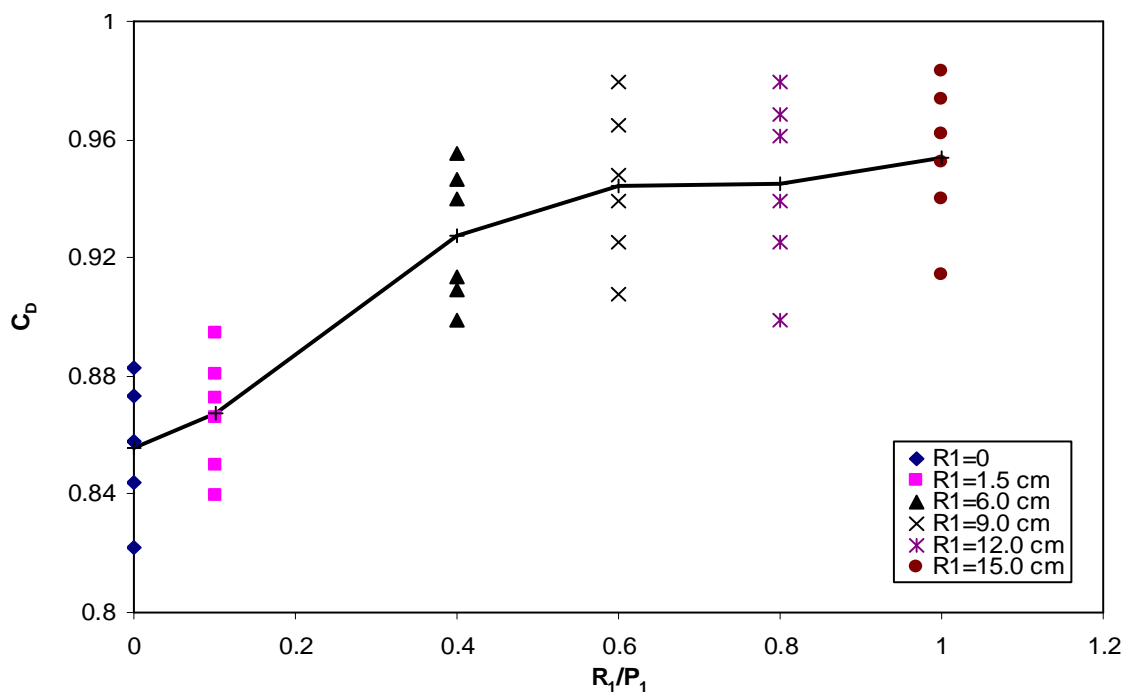

Fig.(4) Variation of average values of $C_{D}$ with $R_{1} / P_{1}$ for vertical upstream weir face

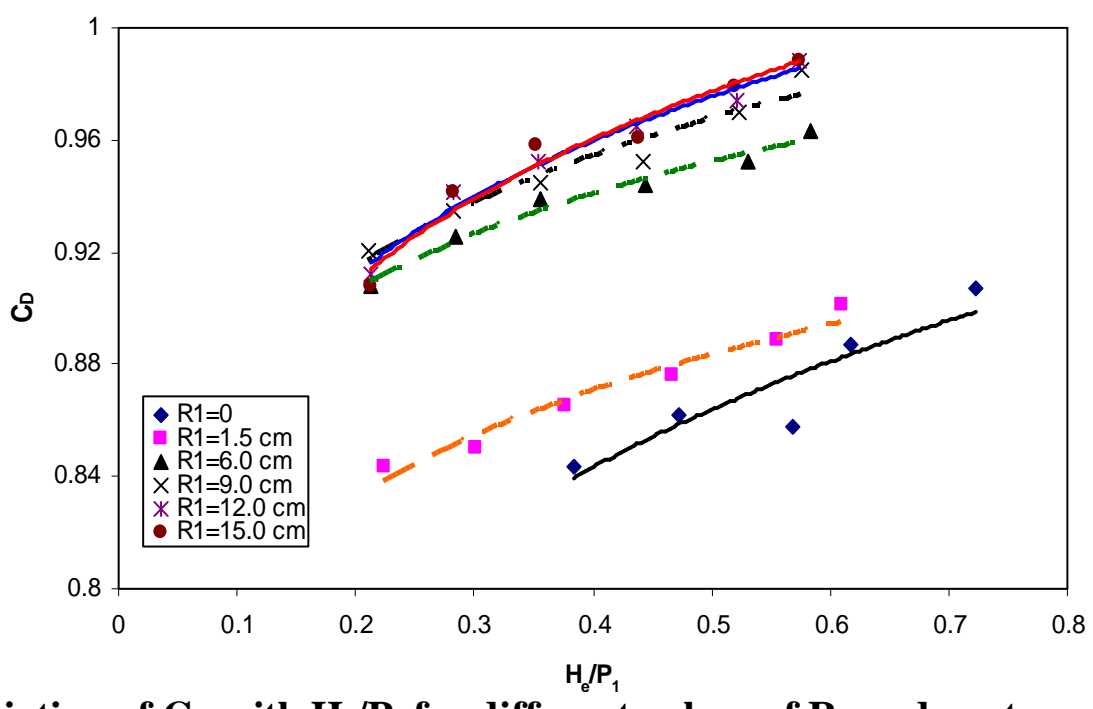

Fig.(5) Variation of $C_{D}$ with $H_{e} / P_{1}$ for different values of $R_{1}$ and upstream weir face

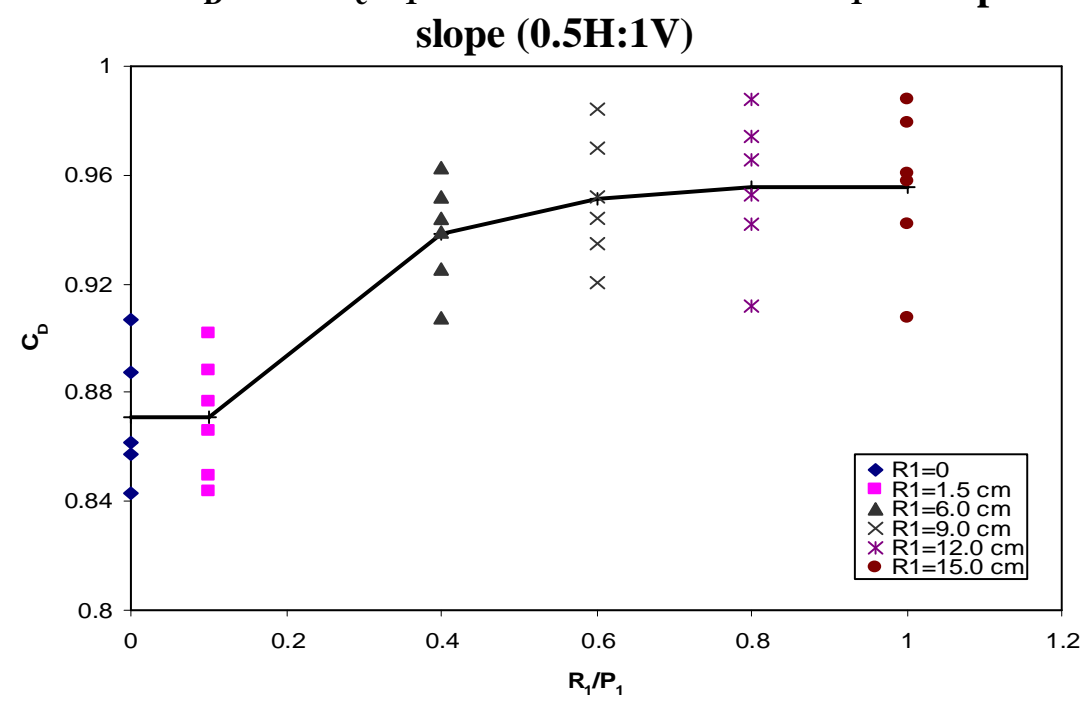

Fig.(6) Variation of average values of $C_{D}$ with $R_{1} / P_{1}$ for upstream weir face slope ( 0.5H:1V) 


\section{Capping Upstream Corner}

Capping upstream corner with a semi-cylinder at the zone of flow separation is to eliminate the effect of flow separation at crest (Fig. (1e)). The variation of $C_{D}$ with $\mathrm{H}_{\mathrm{e}} / \mathrm{P}_{2}$ for different values of semi-cylinder radius $\left(R_{2}=1 \mathrm{~cm}, 2 \mathrm{~cm}, 3 . \mathrm{cm}, 4 \mathrm{~cm}\right.$ and $\left.5 \mathrm{~cm}\right)$ is shown in Fig.(7) from which one may observe that the value of $C_{D}$ increases with the increase of both $H_{e} / P_{2}$ and $R_{2}$ values. The variation of average values of $C_{D}$ with $R_{2} / P_{2}$ is plotted in Fig.(8) showing that the average value of $C_{D}$ reaches the highest value at $R_{2} / P_{2}=0.17$. This means that the effect of stream lines separation vanishes when the value of $R_{2} / P_{2}$ reaches 0.17 after which it remains nearly constant. The effect of sloping upstream face on the discharge coefficient is studied by testing models of constant radius of semi-cylinder cap with different upstream face slopes. Figs (9) to (13) show the variation of $\mathrm{C}_{\mathrm{D}}$ with $\mathrm{H}_{\mathrm{e}} / \mathrm{P}_{2}$ for different slopes and semi-cylinder radii $\left(\mathrm{R}_{2}\right)=1 \mathrm{~cm}, 2 \mathrm{~cm}, 3 \mathrm{~cm}, 4 \mathrm{~cm}$ and $5 \mathrm{~cm}$, respectively. These figures show that the upstream face slope has very little effect on the improvement of discharge coefficient and flow characteristics. This means that the parameter (S) can be dropped from Eq.(6).

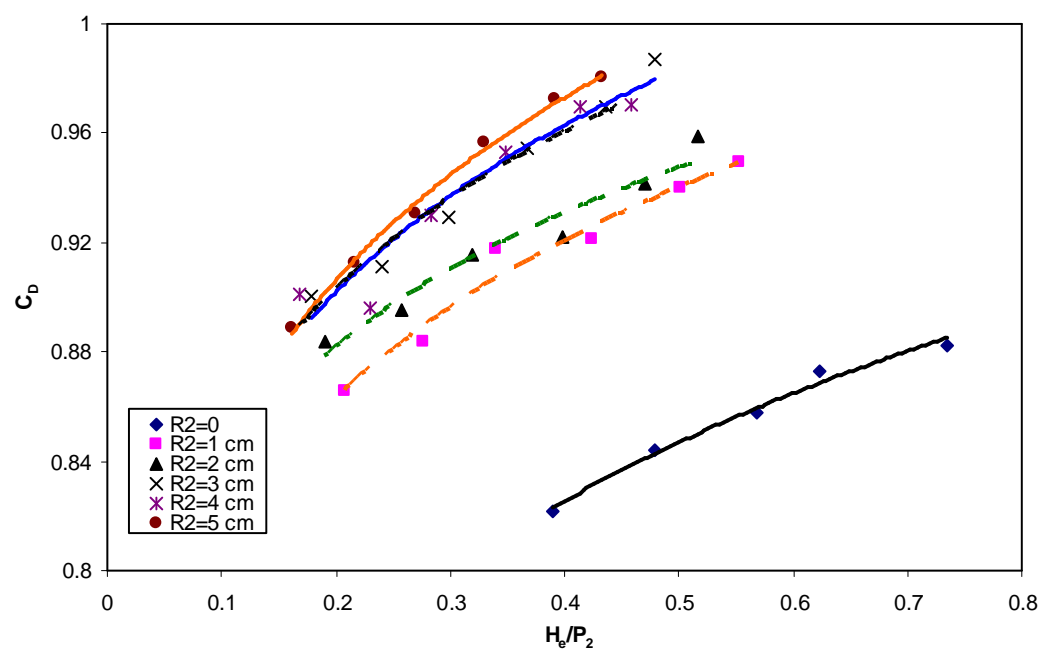

Fig.(7) Variation of $C_{D}$ with $H_{e} / P_{2}$ with different values of $R_{2}$ and vertical upstream weir face

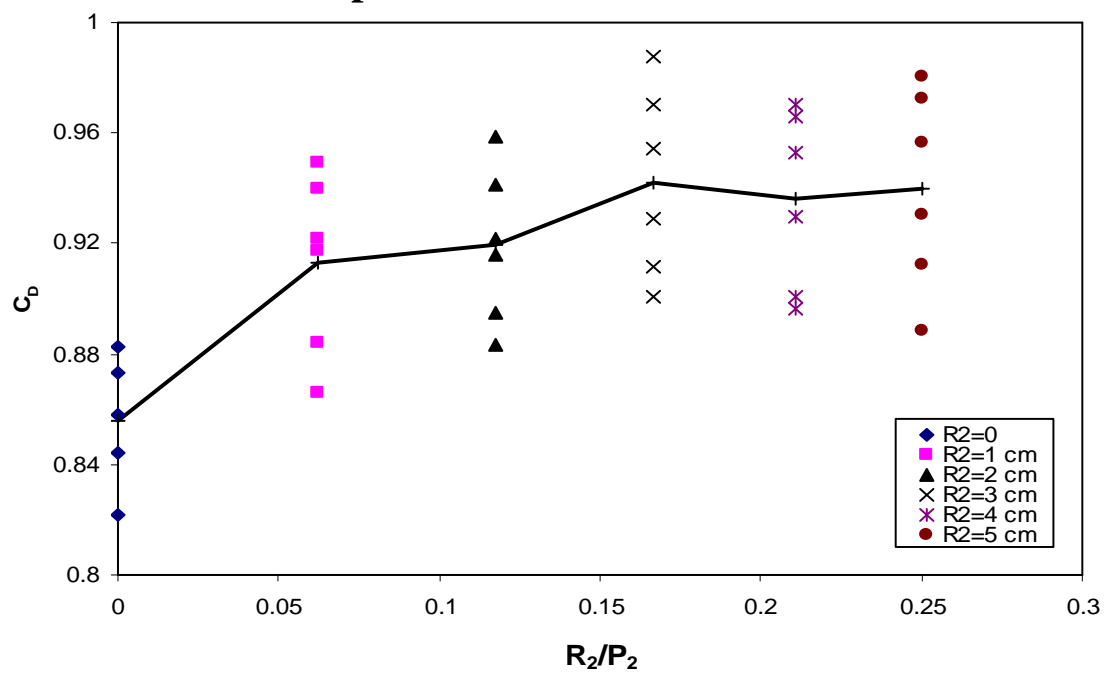

Fig.(8) Variation of average values of $C_{D}$ with $R_{2} / P_{2}$ for vertical upstream weir face 


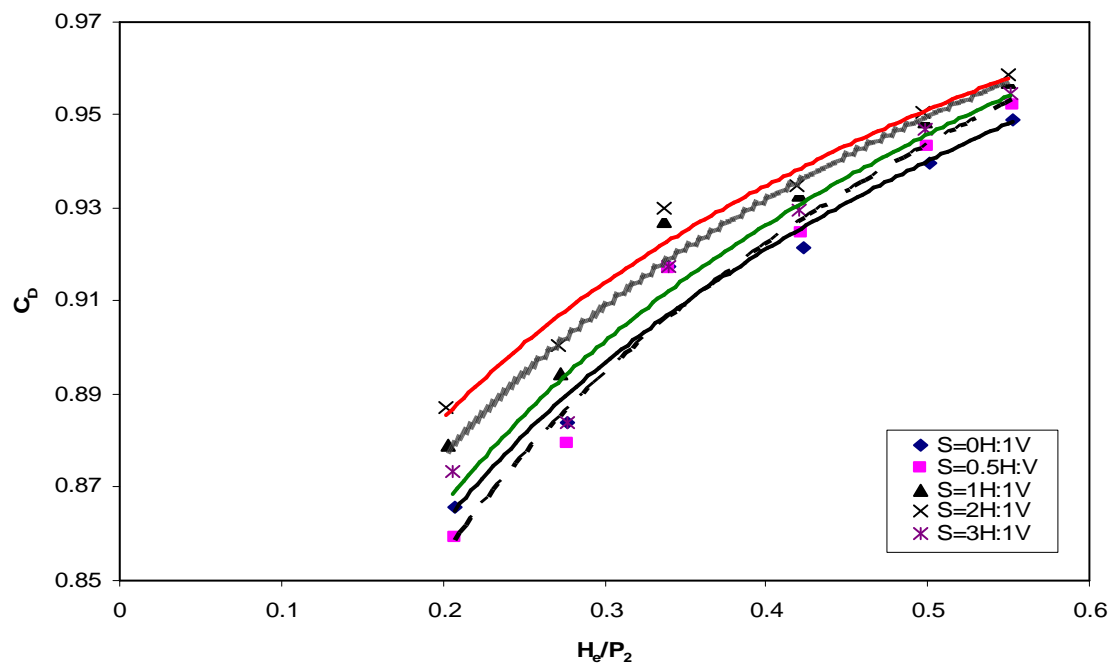

Fig.(9) Variation of $C_{D}$ with $H_{e} / P_{2}$ for different upstream weir face slopes and $R_{2}=1 \mathrm{~cm}$

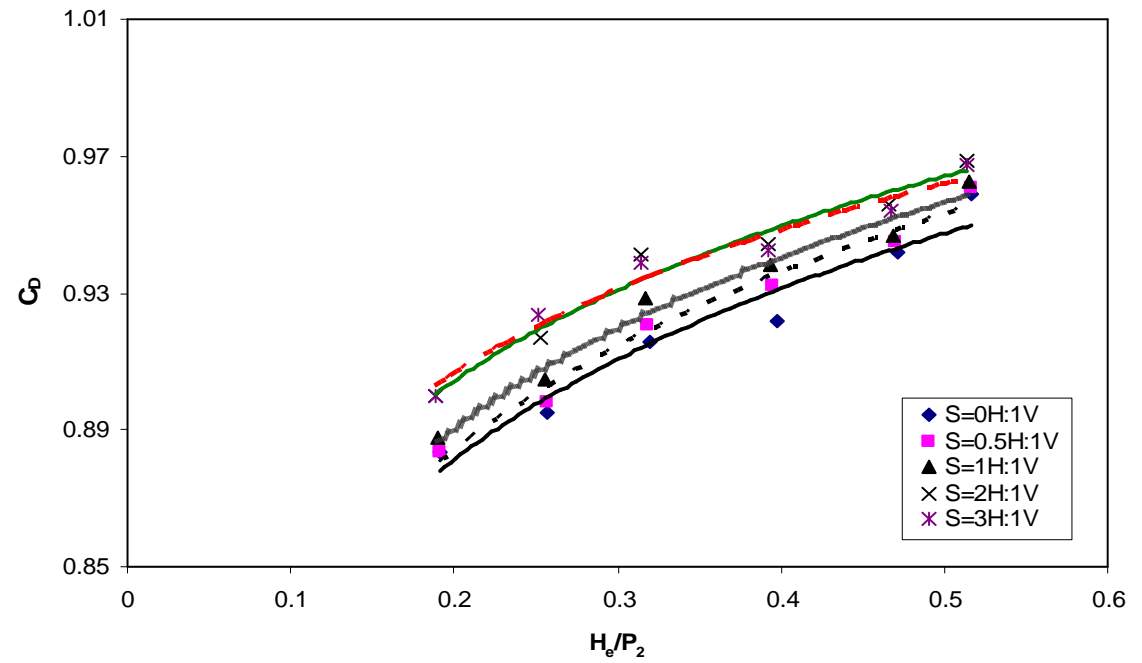

Fig.(10) Variation of $C_{D}$ with $H_{e} / P_{2}$ for different upstream weir face slopes and $R_{2}=2 \mathrm{~cm}$

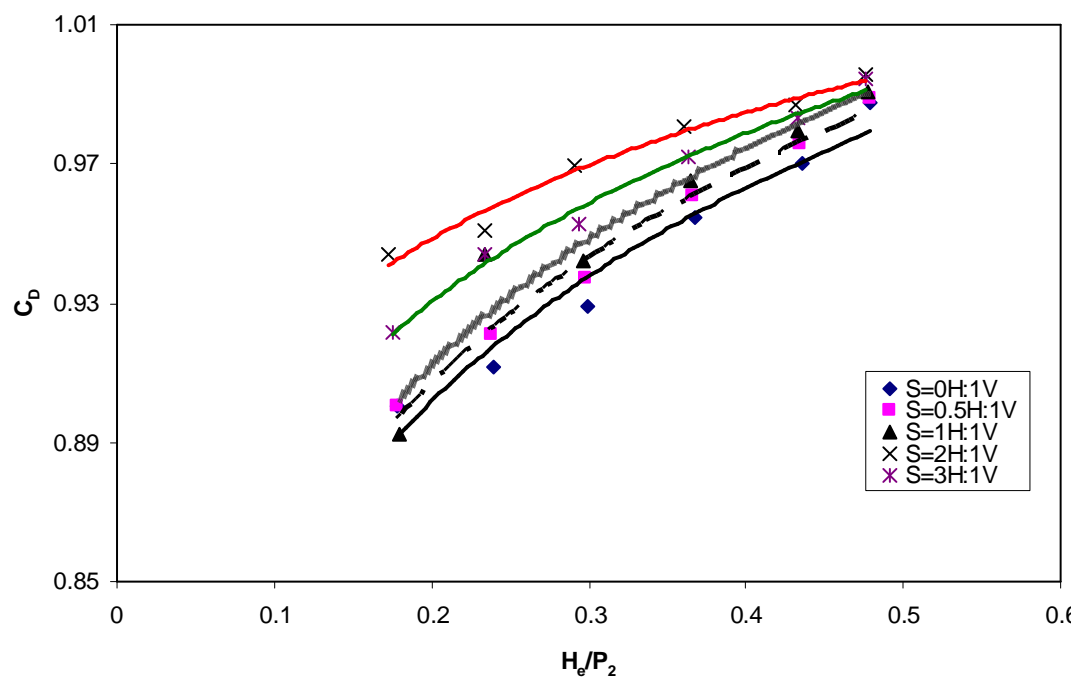

Fig.(11) Variation of $C_{D}$ with $H_{e} / P_{2}$ for different upstream weir face slopes and $R_{2}=3 \mathrm{~cm}$ 


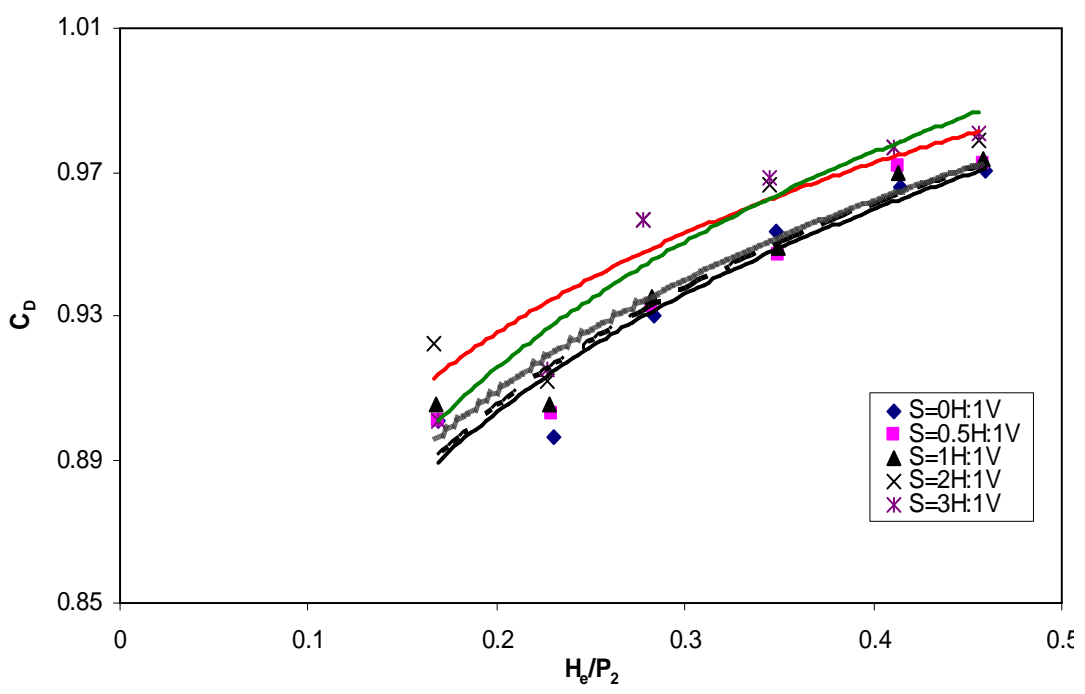

Fig.(12) Variation of $C_{D}$ with $H_{e} / P_{2}$ for different upstream weir face slopes and $R_{2}=4 \mathrm{~cm}$

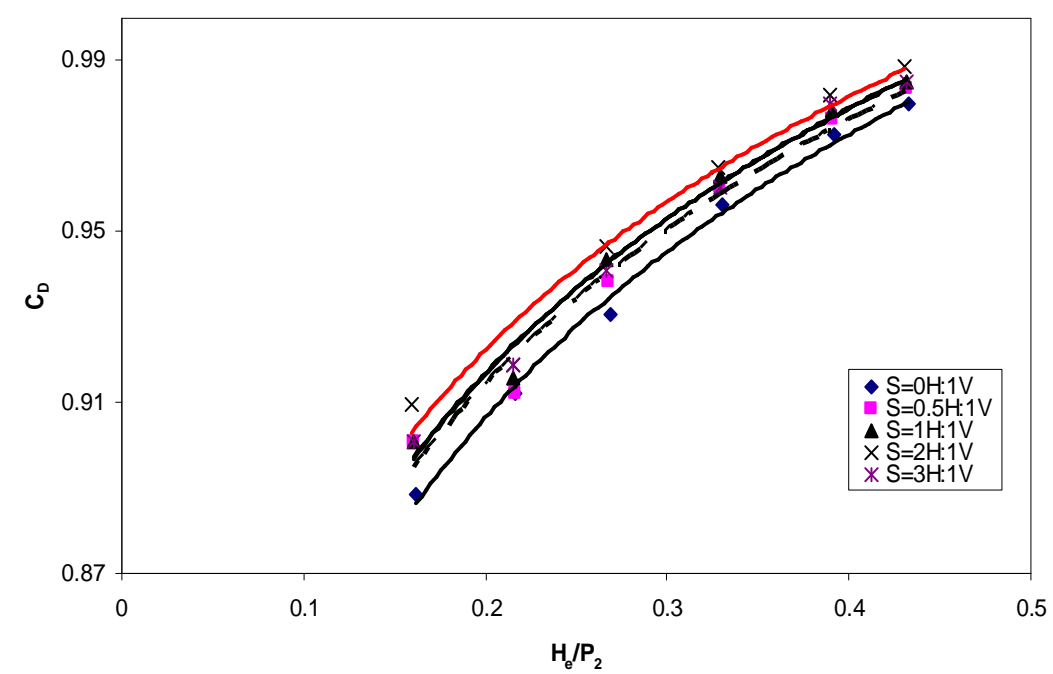

Fig.(13) Variation of $C_{D}$ with $H_{e} / P_{2}$ for different upstream weir face slopes and $R_{2}=5 \mathrm{~cm}$

\section{Empirical Expressions of Discharge Coefficient}

All experimental results of broad crested wires of round upstream corner and vertical upstream face were used as input data in a regression analysis computer program to obtain an empirical power expression for the variation of $\mathrm{C}_{\mathrm{D}}$ with both $\left(\mathrm{H}_{\mathrm{e}} / \mathrm{P}_{1}\right)$ and $\left(\mathrm{R}_{1} / \mathrm{P}_{1}\right)$ :

$C_{D}=1.0256\left(\frac{H_{e}}{P_{1}}\right)^{0.0694}\left(\frac{R_{1}}{P_{1}}\right)^{0.04377}$

with a correlation coefficient $=0.9856$. The relation between $C_{D}$ values predicted by Eq.(7) and values observed experimentally is plotted in Fig.(14) showing good agreement. For all data of capped weirs, another empirical power expression was obtained for the variation of $C_{D}$ with both $\left(\mathrm{H}_{\mathrm{e}} / \mathrm{P}_{2}\right)$ and $\left(\mathrm{R}_{2} / \mathrm{P}_{2}\right)$ for vertical upstream face using the same computer program as:

$C_{D}=1.114\left(\frac{H_{e}}{P_{2}}\right)^{0.0918}\left(\frac{R_{2}}{P_{2}}\right)^{0.0392}$

with a correlation coefficient $=0.9645$. A comparison between $C_{D}$ values predicted by Eq.(8) and observed values experimentally is shown in Fig.(15) showing good agreement. 

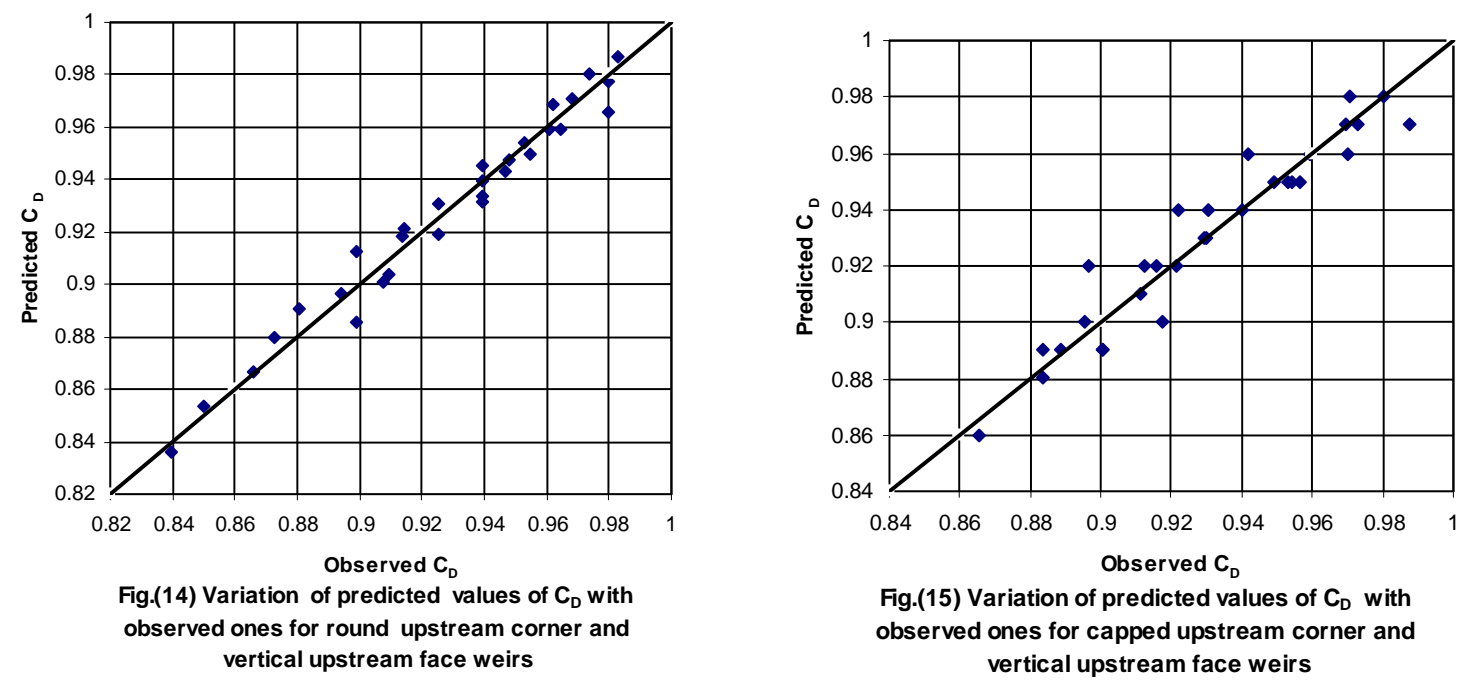

\section{Conclusions}

Within the limits of the experimental data of the present investigation, the following main conclusions can be summarized as:

1. Square edge broad crested weir can be well improved and the discharge coefficient is increased by introducing an upstream face slope of $0.5 \mathrm{H}: 1 \mathrm{~V}$ and this value of slope is quite enough to give high values of discharge coefficient(see Fig.( 2 )).

2. Rounding upstream top corner well reduces the flow separation at the crest and consequently reduces the energy loss and improves the performance of broad crested weirs. The value of $C_{D}$ increases with the increase of $R_{1} / P_{1}$ values reaching its highest value when $\mathrm{R}_{1} / \mathrm{P}_{1}$ values are equal or greater than 0.6 (see Figs(3) and(4)).

3. Capping the upstream corner of the weir with semi-cylinder also eliminates the effect of flow separation and improves the performance of crest. The value of $C_{D}$ increases with the increase of $R_{2} / P_{2}$ values reaching its highest value when $R_{2} / P_{2}$ values reach 0.17 (see Fig.( 8 )). The upstream face slope had very little effect on the improvement of discharge coefficient and performance of the weir.

4. Two empirical power expressions were obtained, one for round upstream corner weirs to estimate discharge coefficient $\left(C_{D}\right)$ in terms of effective head to crest height ratio $\left(\mathrm{H}_{\mathrm{e}} / \mathrm{P}_{1}\right)$ and upstream corner radius to crest height ratio $\left(\mathrm{R}_{1} / \mathrm{P}_{1}\right)$ with a correlation coefficient $=0.9856$ as shown in Eq.(7), while, the second expression for capped upstream corner weirs to estimate $\left(\mathrm{C}_{\mathrm{D}}\right)$ in terms of effective head to crest height ratio $\left(\mathrm{H}_{\mathrm{e}} / \mathrm{P}_{2}\right)$ and cap radius to crest height ratio $\left(\mathrm{R}_{2} / \mathrm{P}_{2}\right)$ with a correlation coefficient $=0.9645$ as shown in Eq.(8).

\section{References}

1. Ackers, P.; White, W.R.; Perkins J.A. and Harrison, A.J.M. (1978), "Weirs and Flumes for Flow Measurement", First Edition, John Wiley and Sons Co., Chichester, England.

2. Boiten,W.(2002), "Flow Measurement Structures", Flow Measurement and Instrumentation, Vol.13, Issues 5-6, December, PP. 203-207. 
3. Bos, M.G.; Replogle, J.A. and Clemmens, A.J. (1984), "Flow Measuring Flumes for Open Channel Systems", John Wiley and Sons, Inc., New York, N.Y.

4. Clemmens, A.J.; Replogle, J.A. and Bos, M.G. (1984), "Rectangular Measuring Flumes fore Lined and Earthen Channels", Journal of Irrigation and Drainage Engineering, ASCE, Vol.110, No.2, PP. 121-137.

5. Crabbe, A.D. (1974), "Some Hydraulic Features of Square-Edged BroadCrested Weir", Water and Water Engineering, Vol.78, No.10, PP. 354-358.

6. Gogus,M. ,Defne, Z. and Ozkandemir,V.(2006), "Broad-Crested Weirs with Rectangular Compound Cross Sections", Journal of Irrigation and Drainage Engineering, Vol.132, No.3, June, PP.272-280.

7. Gonzalez, C.A. and Chanson, H., (2007), "Experimental Measurement of Velocity and Pressure Distribution on a Large Broad-Crested Weir", Flow Measurement and Instrumentation,Vol.18,Issue 3-4,June-August,PP.107113.

8. Govinda Rao, N.S. and Muralidhar, D. (1963), "Discharge Characteristics of Weirs of Finite-Crest Width", Houille Blanche, Vol.18, No.5, PP.537545.

9. Hager, W.H. and Schwalt, M. (1994), "Broad Crested Weir", Journal of Irrigation and Drainage Engineering, Vol.120, No.1, PP. 13-25.

10. Hall, G.W. (1962), "Discharge Characteristics of Broad-Crested Weirs Using Boundary Layer Theory", Proceeding, Institute of Civil Engineers, Vol.22, London, England, PP. 177-190.

11. Johnson, M.C. (2000), "Discharge Coefficient Analysis for Flat-Topped and Sharp-Crested Weirs", Journal of Irrigation Science,Vol.19, PP.133137.

12. Moss, W.D. (1972), "Flow Separation at the Upstream of a Square-Edged Broad-Crested Weir", Journal of Fluid Mechanics, Vol.52, No.2, PP.307320.

13. Ramamurthy, A.S.; Tim, U.S. and Rao, M.V.J. (1988), "Characteristics of Square-Edged and Round-Nosed Broad-Crested Weirs", Journal of Irrigation and Drainage Engineering, ASCE, Vol.114, No.1, PP. 61-73.

14. Rao, N.S.L. and Rao, M.V.J. (1973), "Characteristic of Hydrofoil Weirs", Journal of Hydraulic Division, ASCE, Vol.99, No.2, PP.259-281.

15 Rao, S.S. and Shukla, M.K. (1971), "Characteristics of Flow over Weirs of Finite Crest Width", Journal of Hydraulic Division ASCE, Vol.97, No.11, PP.1807-1816.

16. Replogle, J.A. (1978), "Flumes and Broad-Crested Weirs: Mathematical Modeling and Laboratory Ratings", Flow Measurement of Fluids, H.H. Dijstalberger and E.E.Spenser, Ed., North-Holland Publishing Company, Amsterdam, The Netherlands, PP.321-328

17. Sarker,M.A. and Rhodes,D.G.(2004),"Calculation of Free-Surface Profile over a Rectangular Broad-Crested Weir", Flow Measurement and Instrumentation, Vol.15, Issue 4, August, PP.215-219.

18. Tracy, H.J. (1957), "Discharge Characteristics of Broad-Crested Weirs", U.S. Geological Survey, Circular 397, PP. 1-15. 